\title{
New analytical approach for estimating density of Brazilian tropical woods based on fundamental concepts
}

\author{
Nova abordagem analítica para estimativa da densidade de madeiras \\ tropicais brasileiras baseada em conceitos fundamentais
}

\author{
Tiago Hendrigo de Almeida ${ }^{1}$, Diego Henrique de Almeida², \\ André Luis Christoforo ${ }^{3}$, Tulio Hallak Panzera ${ }^{4}$, Pablo Resende Oliveira ${ }^{4}$ and \\ Francisco Antonio Rocco Lahr ${ }^{1}$
}

\begin{abstract}
Brazilian tropical woods are widely used in civil construction industry as structural items, building components and furniture. Wood physical and mechanical properties are significantly influenced by the moisture content level, which is mostly affected by wood origin and stocking conditions. The development of an analytical equation to estimate apparent wood density $\left(\rho_{\mathrm{MC}}\right)$ based on four fundamental parameters, such as moisture content level (MC), fibre saturation point (FSP), basic density $\left(\rho_{b}\right.$ - ratio between dry mass and saturated volume), and dry density ( $\rho_{0}-$ ratio between dry mass and dry volume), was investigated. This equation was tested in the estimative of wood density at $12 \%$ moisture content $\left(\rho_{12}\right)$. A set of twenty types of Brazilian tropical woods was assessed to verify the predictability of the proposed equation. The Analysis of Variance at $5 \%$ significance level evidenced equivalence of experimental and estimated results of $\rho_{12}$, revealing a high prediction accuracy of the proposed approach.
\end{abstract}

Keywords: Analytical equation; Basic and dry density; Moisture content; Tropical woods; Wood density estimation.

\section{RESUMO}

As madeiras tropicais brasileiras são amplamente utilizadas na indústria da construção civil como itens estruturais, componentes para construção e mobiliário. As propriedades físicas e mecânicas da madeira são significativamente influenciadas pelo nível do teor de umidade, que é principalmente afetado pela origem da madeira e condições de estocagem. O desenvolvimento de uma equação analítica para estimar a densidade aparente da madeira $\left(\rho_{\mathrm{MC}}\right)$ com base em quatro parâmetros fundamentais, como o teor de umidade (MC), o ponto de saturação das fibras (FSP), a densidade básica ( $\rho_{\mathrm{b}}$ - relação entre peso seco e volume saturado) e a densidade seca ( $\rho_{0}$ - relação entre peso seco e volume seco) foi investigado. Esta equação foi testada na estimativa da densidade da madeira a $12 \%$ de umidade $\left(\rho_{12}\right)$. Um conjunto com vinte diferentes espécies de madeiras tropicais brasileiras foi avaliado para verificar a previsibilidade da equação proposta. AAnálise de Variância ao nível de significância de $5 \%$ evidenciou equivalência de resultados experimentais e estimados de $\rho_{12}$, revelando uma alta precisão de previsão da abordagem proposta.

Palavras Chave: Madeiras tropicais, estimativa da densidade aparente, equação analítica, teor de umidade, densidade básica e seca.

\section{INTRODUCTION}

Wood is a widely used construction material that since early ages, fulfilling the needs of society. The fibrous wood originates from trees, whose growth is based on photosynthesis; the basic physiological reaction of plants. It is considered a renewable material and performs a significant role

\footnotetext{
1. Escola de Engenharia de São Carlos - EESC, Universidade de São Paulo - USP. São Carlos, SP, Brazil.

2. Civil Engineering Department, Universidade Federal de Rondônia - UNIR. Porto Velho, RO, Brazil,

3. Civil Engineering Department, Universidade Federal de São Carlos - UFSCar. São Carlos, SP, Brazil.

4. Mechanical Engineering Department, Universidade Federal de São João del-Rei - UFSJ, São João del-Rei, MG, Brazil

*Corresponding author: tiago.hendrigo@gmail.com
} 
on carbon cycle, as trees remove carbon dioxide $\left(\mathrm{CO}_{2}\right)$ from the air during photosynthesis reactions to produce sugar monomers. These monomers form long polymeric chains that originate the wood structural content based on cellulose and other woody chains. In addition, wood contains lignin, a macromolecule, and extractives (CHRISTOFORO et al., 2014; CORADIN; CAMARGO, 2002).

When anatomic definitions are considered, trees are identified as superior plants, since they possess high physiological and anatomical complexity (BRÉMAUD et al., 2013; DADZIE, et al., 2016; FRANKE; QUENNEVILLE, 2013; HE et al., 2016). Trees are classified in botanic as Phanerogams (Spermatophytes), which are subdivided into Gymnosperms and Angiosperms. In Gymnosperms, the most significant class is the coniferous trees or softwoods. Softwood trees constitute the major component in northern hemisphere forests, with higher presence in moderate and cold climates. These woods are largely used in civil construction and furniture industry. Coniferous trees often have evergreen leaves in fish scales or needle shaped. In Brazil, two most noteworthy examples are the Paraná Pine (Araucaria angustifolia) and Pinus species. The predominant anatomic elements are tracheids and medullary rays (CALIL JÚNIOR et al., 2003; CHRISTOFORO et al., 2013).

Angiosperms are represented by dicotyledons (hardwoods), which are the most evolved plants. Many hardwood species with different wood densities are found in Brazil, since they easily adapt to warm climate regions. Some native hardwood trees are found in Amazonian Forest, and other exotic ones such as Eucalyptus, Corymbia, and Tectona and hundreds of species which also belong to Dicotyledon group (ALMEIDA et al., 2017a). Wood is considered a porous capillary structure composed mainly by fibres. Eighty percent of dicotyledons wood volume is composed by longitudinal fibres, and the remaining volume is composed by radial cells (radial parenchyma) (MOREY, 1980).

In Brazil, the usage of extracted wood from the Amazonian Forest reaches significant figures. According to the Brazilian Institute of Management and Forest and Agricultural Certification (LENTINI et al., 2012), 600,000 cubic meters of wood are yearly extracted and tracked. The wood extracted in this region is mainly used as raw material due to its organoleptic properties and mechanical resistance. However, they are mostly commercialized with generic names and without any characterization, with negative influence on their in-service performance. Moisture content level ( $M C$ - see Equation 1) and other physical properties can affect wood response at different stages of extraction, processing, and utilization. The first stage refers to the removal from the forest, the transport, and the initial processing in a sawmill; the second stage consists on drying, machining (including production of reconstructed wood panels), in addition to adhesion; finally, the third stage is related to the quality and performance of final products (KOLLMANN; CÔTÉ, 1968; GALVÃO; JANKOWSKY, 1985).

$$
M C=100 \cdot \frac{m_{M C}-m_{0}}{m_{0}}(\%)\left\{\begin{array}{c}
m_{M C}=\text { sample mass at a given moisture content } \\
m_{0}=\text { dry mass of the wood sample }
\end{array}\right.
$$

The moisture content level in wood (Equation 1) is defined as the mass of the water in wet material divided by the mass of the material in a dry state (KOLLMANN; CÔTÉ, 1968). Fiber Saturation Point (FSP) is the critical condition reached in the process of seasoning in which the wood contains just enough moisture to saturate the cell walls without the presence of any additional moisture in the cell cavities (GALVÃO; JANKOWSKY, 1985). Moisture variations related to FSP can occur mainly when wood is chemically (BRYNE et al., 2010; EPMEIER et al., 2007; LOPES et al., 2013; SEVERO et al., 2012; SLAM et al., 2012; PÁNEK; REINPRECHT, 2016; WANG et al., 2015) or thermally modified (ARAÚJO et al., 2012; BAKAR et al., 2013; LIM et al., 2014; MOURA et al., 2013; ZANUNCIO et al., 2014).

Wood properties have been estimated based on material density, as the density is a physical property of easy measurement (CHRISTOFORO et al., 2016). Apparent density $\left(\rho_{\mathrm{MC}}-\right.$ see Equation 2) and its correlations with other physical and mechanical properties have been studied by a significant number of researchers (ALMEIDA et al., 2017b; 2015; AMOAH et al., 2012; DIAS; LAHR, 2004; MACHADO et al., 2014; MUÑOZ; GETÉ, 2012; NAJI et al., 2014; PONNETH et al., 2014; TRIANOSKI et al., 2014; YEBOAH et al., 2014), as well as the determination of wood responses based on basic density ( $\rho_{\mathrm{b}}$ - see Equation 3 ) (KLOIBER et al., 2012; MOYA; MUNOZ, 2010; PONNETH et al., 2014; SKARVELIS; MANTANIS, 2013; WIEMANN; BRUCE-WILLIAMSON, 2012).

$\rho_{M C}=\frac{m_{M C}}{v_{M C}}\left\{\begin{array}{c}m_{M C}=\text { sample mass at a moisture content level } \\ v_{M C}=\text { sample volume at a moisture content level }\end{array}\right.$ 
Almeida et al. - New analytical approach for estimating density of Brazilian

tropical woods based on fundamental concepts

$\rho_{b}=\frac{m_{0}}{v_{\text {sat }}}\left\{\begin{array}{c}m_{0}=d r y \text { wood mass } \\ v_{\text {sat }}=\text { volume of the saturated sample }\end{array}\right.$

Wood is a material that presents a gradual volume reduction when submitted to drying process at moisture content levels lower than fiber saturation point. This effect occurs in major or minor magnitude depending on the wood kind. This phenomenon is known as wood shrinkage $\left(\beta_{\mathrm{MC}}\right.$ - see Equation 4). The increase in moisture causes the opposite effect, called wood swelling $\left(\alpha_{M C}-\right.$ see Equation 5), as discussed in previous works (ALMEIDA et al., 2015). These effects are the two directions of dimensional stability phenomenon. It is important to highlight that the variation between wood shrinkage and swelling is linearly dependent on moisture content and occurs up to fiber saturation point (ALMEIDA et al., 2017a; GALVÃO; JANKOWSKY, 1985).

$$
\begin{aligned}
& \beta_{M C}=\frac{v_{\text {sat }}-v_{M C}}{v_{\text {sat }}}\left\{\begin{array}{c}
v_{\text {sat }}=\text { volume of the saturated sample } \\
v_{M C}=\text { sample volume at a moisture content level }
\end{array}\right. \\
& \alpha_{M C}=\frac{v_{M C}-v_{0}}{v_{0}}\left\{\begin{array}{c}
v_{0}=\text { dry sample volume } \\
v_{M C}=\text { sample volume at a moisture content level }
\end{array}\right.
\end{aligned}
$$

As previously discussed, density is an easy determining wood property, being widely used for estimating other wood properties. Not only moisture content variations but also stocking conditions can affect the wood responses, mainly the estimated properties based on wood density.

This research aims to develop an analytical equation to estimate the wood density $\left(\rho_{\mathrm{MC}}\right)$ (for any moisture content level between 0 and FSP\%), based on four fundamental parameters such as, the moisture content (MC), fiber saturation point (FSP), basic density $\left(\rho_{\mathrm{b}}\right)$ and dry density $\left(\rho_{0}\right)$.

\section{MATERIAL AND METHODS}

Table 1: Tropical wood species used in this research.

Tabela 1: Espécies de madeira tropicais utilizadas nesta pesquisa.

\begin{tabular}{ccc}
\hline SC & Popular Name & Scientific Name \\
\hline D20 & Cambará Rosa & Erisma sp. \\
D20 & Cedro-amargo & Cedrela sp. \\
D20 & Cedro Doce & Pachira quinata \\
D20 & Branquilho & Sebastiania brasiliensis \\
D30 & Umirana & Qualea retusa \\
D30 & Canafístula & Cassia ferruginea \\
D30 & Catanudo & Calophyllum sp. \\
D30 & Guaiçara & Luetzelburgia auriculata \\
D40 & Catiúba & Qualea paraensis \\
D40 & Vatairea fusca \\
D40 & Angelim Amargoso & Vataieropsis araroba \\
D40 & Angelim Araroba & Andira sp \\
D50 & Cafearana \\
D50 & Castelo & Gossypiospermun praecox \\
D50 & Qualea albiflora \\
D50 & Mandioqueira & Bagassa guianensis \\
D60 & Tatajuba & Copaifera langsdorffii \\
D60 & Copaíba & Dinizia excelsa \\
D60 & Angelim Vermelho & Dipteryx sp. \\
D60 & Champanhe (Cumaru) & Mezilaurus itauba \\
& Itaúba & Parapiptadenia Rigida
\end{tabular}

A set of twenty Brazilian tropical wood species was considered in this work (see Table 1), covering the five strength classes (SC) of hardwoods of the Brazilian standard (under review - PN02:123.10-001-1), with four wood species per SC and leading to more generalized conclusions. 
All specimens were obtained from wood pieces kept in an environment with a $12 \%$ moisture content level. Densities were determined based on different tests conducted according to the recommendations of Annex B of the Brazilian standard ABNT NBR 7190 (ABNT, 1997). Fiber saturation points were determined measuring the moisture content level that starts a dimensional decreasing of the wood samples undergoing a slow air drying process. The properties determined were: apparent density at $12 \%$ of moisture content level $\left(\rho_{12}\right)$, basic density $\left(\rho_{\mathrm{b}}\right)$, dry wood density $\left(\rho_{0}\right)$, and fiber saturation point (FSP). The measurements of standardized wood specimen dimensions were carried out using a digital caliper with a resolution of $0.01 \mathrm{~mm}$. The measurements of wood specimen masses were performed using an analytical balance with $0.01 \mathrm{~g}$ precision. The wood pieces were arranged in homogeneous batches of twelve (12) samples as specified by the Brazilian standard ABNT NBR 7190 (ABNT, 1997). Twenty wood species were examined, twelve samples per wood species and four parameters measured $\left(\rho_{0^{\prime}} \rho_{M C^{\prime}} \rho_{\mathrm{b}^{\prime}}\right.$ FSP); with a total of 960 experimental observations performed.

The analytical equation for estimating wood properties is based on the relationship between volumetric swelling $(\alpha)$ or shrinkage $(\beta)$ and the changes in moisture content level. Based on previous work (KOLLMANN; CÔTÉ, 1986), the dimensional changes of wood ( $\alpha$ and $\beta$ ) was considered to be linearly dependent on the moisture content level for moisture content levels lower than the fiber

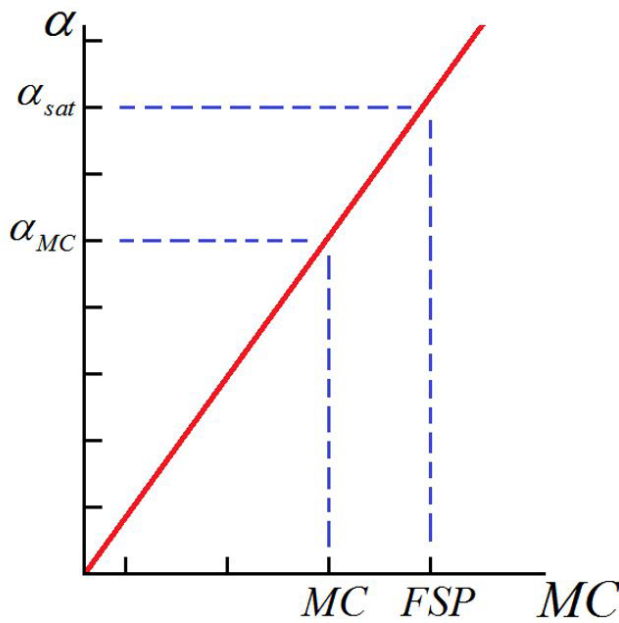

(a)

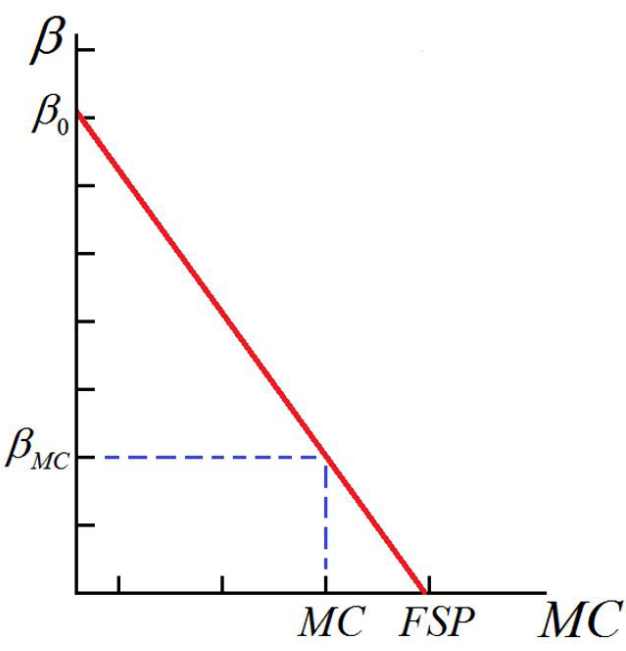

(b)

Figure 1: Variations of swelling properties $[\alpha](a)$ and shrinking properties $[\beta]$ (b) as a function of wood moisture content level $[\mathrm{MC}]$.

Figura 1: Variações das propriedades de inchamento $[\alpha]$ (a) e propriedades de retratibilidade $[\beta]$ (b) como função do teor de umidade [MC].

saturation point (FSP - see Figure 1). In the following formulations, $\alpha_{\mathrm{MC}}$ and $\beta_{\mathrm{MC}}$ are the resulting volumetric swelling and shrinkage coefficients, respectively, at a specific moisture level (MC), which is located between $0 \%$ and FSP. $\alpha_{\text {sat }}$ consists of volumetric swelling at FSP and $\beta_{0}$ is the volumetric shrinkage at $0 \%$ moisture content.

The relationship between volumetric swelling coefficient at specific moisture content $\left(\alpha_{\mathrm{MC}}\right)$ and saturated swelling coefficient $\left(\alpha_{\text {sat }}\right)$ obtained from Figure 1a is shown in Equation 6. Equation 7 presents the association between shrinkage coefficients $\beta_{\mathrm{MC}}$ and $\beta_{0^{\prime}}$ as demonstrated in Figure $1 \mathrm{~b}$.

$\frac{\alpha_{s a t}}{F S P}=\frac{\alpha_{M C}}{M C}$

$\frac{\beta_{0}}{F S P}=\frac{\beta_{M C}}{(F S P-M C)}$

By definition, swelling coefficients $\alpha_{\mathrm{MC}}$ and $\alpha_{\text {sat }}$ can be obtained through Equations 8 and 9, respectively. In these equations, $v_{\mathrm{MC}}$ is the sample volume at a given moisture content $(\mathrm{MC}), v_{\text {sat }}$ is the saturated sample volume, while $v_{0}$ consists in sample volume at $0 \%$ moisture content. 


$$
\begin{aligned}
& v_{M C}=v_{0} \cdot\left(1+\alpha_{M C}\right) \Rightarrow \alpha_{M C}=\frac{v_{M C}-v_{0}}{v_{0}} \\
& v_{\text {sat }}=v_{0} \cdot\left(1+\alpha_{\text {sat }}\right) \Rightarrow \alpha_{\text {sat }}=\frac{v_{\text {sat }}-v_{0}}{v_{0}}
\end{aligned}
$$

When Equations 8 and 9 are replaced in Equation 6, Equation 10 results:

$$
v_{M C}=\left(v_{s a t}-v_{0}\right) \cdot \frac{M C}{F S P}+v_{0}
$$

Equation 1 can be rewritten in terms of moisture content level and dry wood mass to obtain the mass at any given moisture content, resulting in Equation 11.

$$
m_{M C}=m_{0} \cdot\left(1+\frac{M C}{100}\right)
$$

The replacement of Equations 10 and 11 in Equation 2 results in Equation 12.

$$
\frac{\left(1+\frac{M C}{100}\right) \cdot F S P}{\rho_{M C}}=\frac{v_{\text {sat }} \cdot \frac{M C}{100}}{m_{0}}-\frac{v_{0} \cdot \frac{M C}{100}}{m_{0}}+\frac{v_{0} \cdot F S P}{m_{0}}
$$

It is known that wood basic density $\left(\rho_{\mathrm{b}}\right)$ can be obtained by the ratio between dry wood mass $\left(m_{0}\right)$ and saturated sample volume $\left(v_{\text {sat }}\right)$, as shown in Equation 3. In addition, dry wood density $\left(\rho_{0}\right)$ is the ratio between dry wood mass $\left(m_{0}\right)$ and dry sample volume $\left(v_{0}\right)\left[\rho_{0}=m_{0} / v_{0}\right]$. Therefore, Equation 13 can be obtained by replacing the expressions for variables $v_{\text {sat }}$ and $v_{0}\left(v_{\text {sat }}=m_{0} / \rho_{\mathrm{b}^{\prime}}\right.$ and $\left.v_{0}=m_{0} / \rho_{0}\right)$ in Equation 12. This expression represents the relationship between volumetric swelling and wood moisture content variation.

$$
\frac{M C}{\rho_{b}}=\frac{\left(1+\frac{M C}{100}\right) \cdot F S P}{\rho_{M C}}-\frac{(F S P-M C)}{\rho_{0}}
$$

In analogy to the previous discussion for swelling coefficients, the shrinkage coefficients $\left(\beta_{\mathrm{MC}}\right.$ and $\left.\beta_{0}\right)$ can be obtained through Equations 14 and 15, respectively. In these equations, $v_{\mathrm{MC}}$ is the sample volume at a specific moisture content level, $v_{\text {sat }}$ is the sample volume at FSP, and $v_{0}$ is the sample volume at $0 \%$ moisture content level.

$$
\begin{aligned}
& v_{M C}=v_{\text {sat }} \cdot\left(1-\beta_{M C}\right) \Rightarrow \beta_{M C}=\frac{v_{\text {sat }}-v_{M C}}{v_{\text {sat }}} \\
& v_{0}=v_{\text {sat }} \cdot\left(1-\beta_{0}\right) \Rightarrow \beta_{0}=\frac{v_{\text {sat }}-v_{0}}{v_{\text {sat }}}
\end{aligned}
$$

Equations 14 and 15 are substituted in Equation 7, resulting in Equation 16.

$$
v_{M C}=v_{\text {sat }}-\left(v_{\text {sat }}-v_{0}\right) \cdot \frac{(F S P-M C)}{F S P}
$$

The replacement of Equations 11 and 16 in Equation 2 results in Equation 17.

$$
\frac{\left(1+\frac{M C}{100}\right) \cdot F S P}{\rho_{M C}}=\frac{v_{s a t} \cdot F S P}{m_{0}}-\frac{v_{s a t} \cdot(F S P-M C)}{m_{0}}+\frac{v_{0} \cdot(F S P-M C)}{m_{0}}
$$

Equation 18 can be obtained by replacing the expressions for variables $v_{\text {sat }}$ and $v_{0}\left(v_{\text {sat }}=m_{0} / \rho_{\mathrm{b}^{\prime}}\right.$ and $\left.v_{0}=m_{0} / \rho_{0}\right)$ in Equation 17. This expression represents the relationship between volumetric shrinkage and wood moisture content variation. It should be evidenced that Equations 13 and 18, although developed in different ways, are equivalent expressions.

$$
\frac{M C}{\rho_{b}}=\frac{\left(1+\frac{M C}{100}\right) \cdot F S P}{\rho_{M C}}-\frac{(F S P-M C)}{\rho_{0}}
$$

This expression allows determining the wood density at any moisture content level $\left(\rho_{\mathrm{MC}}\right)$ based on the dry density and basic density values. For the usage of this equation an average value of FSP moisture content can be considered. This formulation can also be used to set the wood density at any moisture 
content level (between 0 and FSP\%) to the wood density at 12\% moisture content (reference value of the Brazilian code), just by knowing the dry density.

In order to validate the proposed approach, a density at $12 \%$ moisture content $\left(\rho_{12}\right)$ was estimated using Equation 13 (or Equation 18). In this way, fiber saturation point (FSP), basic density $\left(\rho_{\mathrm{b}}\right)$, and dry wood density $\left(\rho_{0}\right)$ were determined for each tested sample. Twelve (12) samples per wood species were used to calculate the evaluated properties, totaling in 240 observations.

The equivalence of experimental and estimated density results at $12 \%$ moisture content level was verified via Analysis of Variance (ANOVA) using the statistical software Minitab v. 14 at $5 \%$ significance level. The statistical analysis evaluated two hypotheses, the null-hypothesis $\left(\mathrm{H}_{0}\right)$, which consisted on the equivalence of both experimental and theoretical densities, and the non-equivalence hypothesis $\left(\mathrm{H}_{1}\right)$. The equivalence was verified by the P-Values. The null-hypothesis $\left(\mathrm{H}_{0}\right)$ is accepted when both densities are equivalent; in this case the P-Value must be equal or superior to 0.05. When the P-Value is lower than $0.05, \mathrm{H}_{0}$ is rejected and both means are significantly different. The Analysis of Variance (ANOVA) was validated via the Anderson-Darling normality test (AD) and the variances homogeneity test (F-test). Both tests were assessed at 5\% significance level. P-Values higher than 0.05 indicate the experimental data follow a normal distribution and the variances of both groups are equivalent, validating the ANOVA results.

\section{RESULTS AND DISCUSSION}

Average values $(x)$ and variation coefficients (VC) of the experimental data obtained for the investigated physical properties $\left(\rho_{12^{\prime}} \rho_{0^{\prime}} \rho_{\mathrm{b}^{\prime}}\right.$ FSP) are shown in Table 2. In addition, estimated density values at $12 \%$ moisture content level $\left(\rho_{12, \text { est }}\right)$ are also presented. Figure 2 shows the mean values of $\rho_{12, \exp }$ and $\rho_{12, \text { est }}$ obtained for all assessed species.

Table 2: Average values and variation coefficients of apparent densities.

Tabela 2: Valores médios e coeficientes de variação da densidade aparente.

\begin{tabular}{|c|c|c|c|c|c|c|c|c|c|c|}
\hline \multirow{2}{*}{ Properties } & \multicolumn{2}{|c|}{ Cambará Rosa } & \multicolumn{2}{|c|}{ Cedro-amargo } & \multicolumn{2}{|c|}{ Cedro Doce } & \multicolumn{2}{|c|}{ Canafístula } & \multicolumn{2}{|c|}{ Catanudo } \\
\hline & $x$ & VC (\%) & $x$ & VC (\%) & $x$ & VC (\%) & $x$ & VC (\%) & $x$ & VC (\%) \\
\hline$\rho_{12}\left(\mathrm{~g} / \mathrm{cm}^{3}\right)$ & 0.68 & 4.77 & 0.50 & 6.40 & 0.50 & 5.35 & 0.86 & 8.80 & 0.80 & 4.73 \\
\hline$\rho_{0}\left(\mathrm{~g} / \mathrm{cm}^{3}\right)$ & 0.64 & 5.44 & 0.47 & 8.69 & 0.48 & 6.17 & 0.84 & 9.56 & 0.78 & 5.53 \\
\hline$\rho_{\mathrm{b}}\left(\mathrm{g} / \mathrm{cm}^{3}\right)$ & 0.51 & 7.72 & 0.42 & 8.91 & 0.42 & 9.37 & 0.72 & 5.15 & 0.64 & 4.06 \\
\hline FSP (\%) & 22.32 & 6.31 & 18.00 & 12.77 & 25.34 & 17.60 & 21.75 & 7.66 & 23.32 & 6.78 \\
\hline$\rho_{12, \text { est }}\left(\mathrm{g} / \mathrm{cm}^{3}\right)$ & 0.58 & 4.96 & 0.44 & 5.76 & 0.42 & 5.28 & 0.72 & 8.20 & 0.67 & 4.21 \\
\hline \multirow{2}{*}{ Properties } & \multicolumn{2}{|c|}{ Ang. Amargoso } & \multicolumn{2}{|c|}{ Ang. Araroba } & \multicolumn{2}{|c|}{ Castelo } & \multicolumn{2}{|c|}{ Mandioqueira } & \multicolumn{2}{|c|}{ Tatajuba } \\
\hline & $x$ & VC (\%) & $x$ & VC (\%) & $\mathbf{x}$ & VC (\%) & $\mathbf{x}$ & VC (\%) & $\mathbf{x}$ & VC (\%) \\
\hline$\rho_{12}\left(\mathrm{~g} / \mathrm{cm}^{3}\right)$ & 0.77 & 4.72 & 0.69 & 9.62 & 0.77 & 7.10 & 0.86 & 2.97 & 0.95 & 5.96 \\
\hline$\rho_{0}\left(\mathrm{~g} / \mathrm{cm}^{3}\right)$ & 0.75 & 5.84 & 0.67 & 10.40 & 0.74 & 7.87 & 0.83 & 2.67 & 0.93 & 6.70 \\
\hline$\rho_{\mathrm{b}}\left(\mathrm{g} / \mathrm{cm}^{3}\right)$ & 0.62 & 4.81 & 0.54 & 7.97 & 0.62 & 5.46 & 0.67 & 2.78 & 0.72 & 6.25 \\
\hline FSP (\%) & 17.87 & 5.60 & 19.96 & 12.47 & 23.68 & 12.61 & 23.29 & 21.13 & 22.80 & 17.25 \\
\hline$\rho_{12, \text { est }}\left(\mathrm{g} / \mathrm{cm}^{3}\right)$ & 0.66 & 4.28 & 0.59 & 9.56 & 0.64 & 7.27 & 0.71 & 2.67 & 0.78 & 7.19 \\
\hline \multirow{2}{*}{ Properties } & \multicolumn{2}{|c|}{ Ang. Vermelho } & \multicolumn{2}{|c|}{ Champanhe } & \multicolumn{2}{|c|}{ Itaúba } & \multicolumn{2}{|c|}{ Umirana } & \multicolumn{2}{|c|}{ Guaiçara } \\
\hline & $x$ & VC (\%) & $x$ & VC (\%) & $x$ & VC (\%) & $x$ & VC (\%) & $\mathbf{x}$ & VC (\%) \\
\hline$\rho_{12}\left(\mathrm{~g} / \mathrm{cm}^{3}\right)$ & 1.13 & 9.75 & 1.09 & 3.08 & 0.91 & 3.62 & 0.72 & 4.79 & 1.09 & 2.43 \\
\hline$\rho_{0}\left(\mathrm{~g} / \mathrm{cm}^{3}\right)$ & 1.12 & 9.82 & 1.08 & 3.28 & 0.90 & 4.19 & 0.68 & 4.71 & 1.08 & 3.28 \\
\hline$\rho_{\mathrm{b}}\left(\mathrm{g} / \mathrm{cm}^{3}\right)$ & 0.89 & 5.26 & 0.91 & 5.08 & 0.78 & 4.07 & 0.59 & 6.32 & 0.88 & 2.32 \\
\hline FSP (\%) & 25.53 & 8.98 & 21.16 & 7.04 & 19.62 & 7.37 & 19.29 & 14.36 & 27.36 & 11.31 \\
\hline$\rho_{12, \text { est }}\left(\mathrm{g} / \mathrm{cm}^{3}\right)$ & 0.91 & 10.15 & 0.90 & 2.98 & 0.77 & 3.13 & 0.62 & 4.79 & 0.86 & 2.67 \\
\hline \multirow{2}{*}{ Properties } & \multicolumn{2}{|c|}{ Cafearana } & \multicolumn{2}{|c|}{ Copaíba } & \multicolumn{2}{|c|}{ Guarucaia } & \multicolumn{2}{|c|}{ Branquilho } & \multicolumn{2}{|c|}{ Catiuba } \\
\hline & $x$ & VC (\%) & $x$ & VC (\%) & $x$ & VC (\%) & $x$ & VC (\%) & $x$ & VC (\%) \\
\hline$\rho_{12}\left(\mathrm{~g} / \mathrm{cm}^{3}\right)$ & 0.67 & 8.39 & 0.69 & 2.33 & 0.92 & 7.30 & 0.81 & 6.32 & 1.15 & 5.53 \\
\hline$\rho_{0}\left(\mathrm{~g} / \mathrm{cm}^{3}\right)$ & 0.63 & 8.47 & 0.67 & 2.23 & 0.91 & 7.99 & 0.78 & 7.24 & 1.13 & 5.77 \\
\hline$\rho_{\mathrm{b}}\left(\mathrm{g} / \mathrm{cm}^{3}\right)$ & 0.56 & 9.90 & 0.54 & 4.66 & 0.79 & 7.13 & 0.71 & 7.63 & 0.94 & 3.89 \\
\hline FSP (\%) & 20.21 & 12.25 & 21.33 & 9.81 & 20.17 & 9.01 & 27.23 & 9.44 & 22.44 & 15.71 \\
\hline$\rho_{12, \text { est }}\left(\mathrm{g} / \mathrm{cm}^{3}\right)$ & 0.58 & 8.21 & 0.58 & 2.14 & 0.78 & 7.08 & 0.68 & 12.47 & 0.95 & 6.74 \\
\hline
\end{tabular}




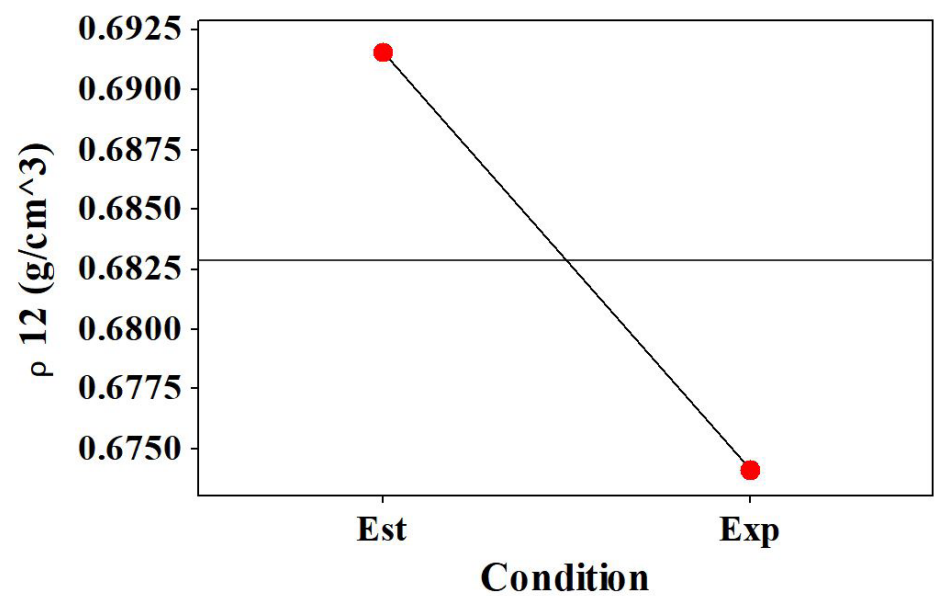

Figure 2: Mean values plot for experimental densities at $12 \%$ moisture content level $\left(\rho_{12, \exp }\right)$ and estimated densities $\left(\rho_{12, \text { est }}\right)$.

Figura 2: Valores médios experimentais $\left(\rho_{12, \text { exp }}\right)$ e estimados $\left(\rho_{12, \text { est }}\right)$ para a densidade aparente.

These experimental results are similar to the ones found in the works of Galvão and Jankowsky, 1985 and Kollmann and Coté, 1968. Therefore, our results are considered consistent.

Significant variations in density values and fiber saturation points were achieved (see Table 2), being attributed to the wide range of investigated wood species. Fiber saturation point mean value obtained for the experimental set was 22.13\% (similar value to the ones found by Christoforo et al.,

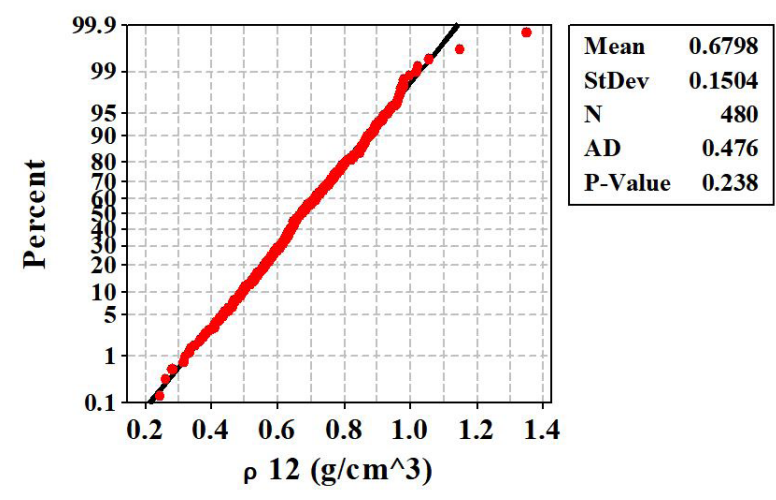

(a)

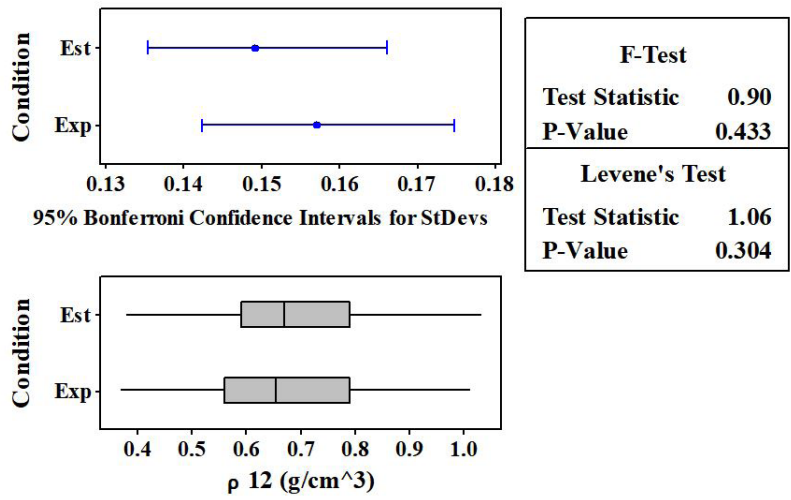

(b)

Figure 3: Results of normality (a) and variance homogeneity (b) tests for the apparent density mean values.

Figura 3: Resultados dos testes de normalidade (a) e de homogeneidade de variância (b) para os valores médios de densidade aparente.

2016 for Brazilian tropical wood species). This parameter was, up to current date, unknown in the literature for tropical wood species. Experimental mean density value at $12 \%$ moisture content was $\rho_{12, \exp }=0.67 \mathrm{~g} / \mathrm{cm}^{3}$ (see Figure 2), whereas estimated mean density value was $\rho_{12, \text { est }}=0.69 \mathrm{~g} / \mathrm{cm}^{3}$, according to Equation 13 (or Equation 18), revealing a small percent variation of $2.99 \%$. Figure 3 presents the normality and variance homogeneity tests. P-values were superior to 0.05 , validating the ANOVA statistical model.

Table 3 presents the ANOVA results for the equivalence of densities at 12\% moisture content level considering 20 wood species. DF refers to the model degrees of freedom, SS is the sum of squares of the values, MS is the mean of squares of the values, $\mathrm{F}$ is the Fisher statistic, and P-Value is the resulting P probability. 
Table 3: ANOVA results for the experimental and analytical calculated density.

Tabela 3: ANOVA para os resultados de densidade obtidos experimentalmente e calculados analiticamente.

\begin{tabular}{cccccc}
\hline Source & DF & SS & MS & F & P-value \\
\hline Condition & 1 & 0.0369 & 0.0369 & 1.58 & 0.210 \\
Error & 478 & 11.1989 & 0.0234 & & \\
Total & 479 & 11.2358 & & & \\
\hline
\end{tabular}

The P-value (0.210) presented in Table 3 is higher than 0.05, which demonstrates the null-hypothesis was accepted. In other words, the mean densities for experimental observations and analytical calculations were equivalent, validating the developed equations (Equation 13 or 18). The high predictability achieved by this equation also demonstrates the effect of these four fundamental parameters on the wood apparent densities. The authors emphasize that it was not possible to compare and discuss the obtained results, since there is not enough information in the literature on this topic for suitable comparisons.

\section{CONCLUSIONS}

The statistical analysis revealed that the analytical approach was able to replicate the interaction between the densities and fiber saturation point (FSP) for the investigated woods with moisture content levels between $0 \%$ and FSP. The mean FSP for a set of twenty tropical wood species was $22.13 \%$ (which can be used in the application of the expression generated hare). The equation developed was statistically adequate to obtain a quick estimative of physical parameters for Brazilian tropical woods, as well as for setting wood density values for the $12 \%$ moisture content state. Finally, this equation can support the utilization of Brazilian tropical woods as raw material in a variety of industrial areas, besides reinforcing previous concepts in wood physical properties.

\section{REFERENCES}

ABNT - ASSOCIAÇÃO BRASILEIRA DE NORMAS TÉCNICAS. NBR 7190 - Projeto de estruturas de madeira. Rio de Janeiro, 1997. 107 p.

ALMEIDA, T. H.; CHRISTOFORO, A. L.; LAHR, F. A. R. Study of dimensional stability of Brazilian tropical wood species. Chisinau: Lambert Academic Publishing, 2017a. 112 p.

ALMEIDA, T. H.; ALMEIDA, D. H.; ARAÚJO, V. A.; SILVA, S. A. M.; CHRISTOFORO, A. L.; LAHR, F. A. R. Density as estimator of dimensional stability quantities of Brazilian tropical woods. BioResources, Raleigh, v. 12, n. 3, p. 6579-6590, 2017b.

ALMEIDA, T. H.; ALMEIDA, D. H.; MARCOLIN, L. A.; GONÇALVES, D.; CHRISTOFORO, A. L.; LAHR, F. A. R. Correlation between dry density and volumetric shrinkage coefficient of three Brazilian tropical wood species. International Journal of Materials Engineering, Rosemead, v. 5, n. 1, p. 1-4, 2015.

AMOAH, M.; APPIAH-YEBOAHAND, J.; OKAI, R. Characterization of physical and mechanical properties of branch, stem and root wood of Iroko and Emire tropical trees. Research Journal of Applied Sciences, Engineering and Technology, New York, v. 4, n. 12, p. 1755-1761, 2012.

ARAÚJO, S. O.; VITAL, B. R.; MENDOZA, Z. M. S. H.; VIEIRA, T. A.; CARNEIRO, A. C. O. Propriedades de madeiras termorretificadas de Eucalyptus grandis e sp. Scientia Forestalis, Piracicaba, v. 40, n. 95, p. 327-336, 2012.

BAKAR, B. F. A; HIZIROGLU, S.; TAHIR, P. M. Properties of some thermally modified wood species. Materials and Design, Vienna, v. 43, p. 348-355, 2013.

BRÉMAUD, I.; RUELLE, J.; THIBAUT, A.; THIBAUT, B. Changes in viscoelastic vibrational properties between compression and normal wood: roles of microfibril angle and of lignin. International Journal of the Biology, Chemistry, Physics, and Technology of Wood, Villeurbanne, v. 67, n. 1, p. 75-85, 2013.

BRYNE, L. E.; LAUSMAA, J.; ERNSTSSON, M.; ENGLUND, F.; WALINDER, M. E. P. Ageing of modified wood. Part 2: Determination of surface composition of acetylated, furfurylated, and thermally modified wood by 
Almeida et al. - New analytical approach for estimating density of Brazilian

tropical woods based on fundamental concepts

XPS and ToF-SIMS. International Journal of the Biology, Chemistry, Physics, and Technology of Wood, Villeurbanne, v. 64, n. 3, p. 305-313, 2010.

CALIL JUNIOR, C.; LAHR, F. A. R.; DIAS, A. A. Dimensionamento de elementos estruturais de madeira. Barueri: Manole, 2003. 152 p.

CHRISTOFORO, A. L.; AlMEIDA, T. H.; AlMEIDA, D. H.; SANTOS, J. C.; PANZERA, T. H.; LAHR, F. A. R. Shrinkage for some wood species estimated by density. International Journal of Materials Engineering, Rosemead, v. 6, n. 2, p. 23-27, 2016

CHRISTOFORO, A. L.; PANZERA, T. H.; MOLINA, J. C.; ALMEIDA, D. H.; LAHR, F. A. R.; CHAHUD, E. Determinação do módulo de elasticidade na compressão paralela às fibras da madeira: proposta de metodologia alternativa. Construindo, Belo Horizonte, v. 6, n. 2, p. 20-25, 2014.

CHRISTOFORO, A. L.; BLECHA, K. A.; CARVALHO, A. L. C.; RESENDE, L. F. S.; LAHR, F. A. R. Characterization of tropical wood species for use in civil constructions. Journal of Civil Engineering Research, Rosemead, v. 3, n. 3, p. 98-103, 2013

CORADIN, V. T. R.; CAMARGO, J. A. Q. A estrutura anatômica da madeira e princípios para sua identificação. Brasília: SFB, 2002. 28 p.

DADZIE, P. K.; AMOAH, M.; FRIMPONG-MENSAH, K.; OHENEBA-KWARTENG, F. Some physical, mechanical and anatomical characteristics of stemwood and branchwood of two hardwood species used for structural applications. Materials and Structures, Cham, v. 49, n. 12, p. 4947-4958, 2016.

DIAS, F. M.; LAHR, F. A. R. Estimativa de propriedades de resistência e rigidez da madeira através da densidade aparente. Scientia Forestalis, Piracicaba, n. 65, p. 102-113, 2004.

EPMEIER, H.; JOHANSSON, M.; KLIGER, R.; WESTIN, M. Material properties and their interrelation in chemically modified clear wood of Scots pine. International Journal of the Biology, Chemistry, Physics, and Technology of Wood, Villeurbanne, v. 61, n. b, p. 34-42, 2007.

FRANKE, S.; QUENNEVILLE, P. Compression behavior and material parameters of Radiata Pine at different orientations to the grain. Journal of Materials in Civil Engineering, Reston, v. 25, n. 10, p. 1514-1523, 2013.

GALVÃO, A. P. M.; JANKOWSKY, I. P. Secagem racional da madeira. São Paulo: Nobel, 1985. 111 p.

HE, H.; LOU, X.; LIN, E.; YU, Y.; TONG, Z.; HUANG, H. Xylem characteristics of tension wood and endogenous hormones distributions during its early formation period in Betula luminifera. Scientia Silvae Sinicae, Beijing, v. 52, n. 10 , p. 38-44, 2016.

ISLAM, S.; HAMDAN, S.; RAHMAN, R.; JUSOH, I.; AHMED, A. S.; IDRUS, M. Dynamic Young's modulus, morphological, and thermal stability of 5 tropical light hardwoods modified by benzene diazonium salt treatment. BioResources, Raleigh, v. 6, n. 1, p. 737-750, 2011

KLOIBER, M.; TIPPNER, J. A. N.; PRAUS, L.; HRIVNÁK, J. Experimental verification of a new tool for wood mechanical resistance measurement. Wood Research, Bratislava, v. 57, n. 3, p. 383-398, 2012.

KOLLMANN, F.; CÔTÉ, W. A. Principles of wood science and technology. München: Springer Verlag, 1968. 159 p.

LENTINI, M. W.; GOMES, P. C.; SOBRAL, P. Acertando o alvo 3: desvendando o mercado brasileiro de madeira amazônica certificada FSC ${ }^{\circledR}$. Piracicaba: IMAFLORA, 2012. 73 p.

LIM, H. M.; HONG, S. H.; KANG, H. Y. Investigation of the color change and physical properties of heat-treated Pinus koraiensis square lumbers. Journal of the Korean Wood Science and Technology, Seul, v. 42, n. 1, p. 13-19, 2014

LOPES, D. B.; MAY, C.; MILITZ, H. Physical properties of Portuguese pinewood chemically modified. Ciência e Tecnologia dos Materiais, Cham, v. 25, n. 2, p. 121-128, 2013.

MACHADO, J. S.; LOUZADA, J. L.; SANTOS, A. J. A.; NUNES, L.; ANJOS, O.; RODRIGUES, J.; SIMÕES, R. M. S.; PEREIRA, H. Variation of wood density and mechanical properties of blackwood (Acacia melanoxylon R. Br.). Materials and Design, Vienna, v. 56, p. 975-980, 2014. 
MOREY, P. R. O crescimento das árvores. São Paulo: EDUSP, 1980. 72 p.

MOURA, L. F.; BRITO, J. O.; NOLASCO, A. M.; ULIANA, L. R.; MUNIZ, G. I. B. Evaluation of coating performance and color stability on thermally rectified Eucalyptus grandis and Pinus caribaea var. hondurensis woods. Wood Research, Bratislava, v. 58, n. 2, p. 231-242, 2013.

MOYA, R.; MUNOZ, F. Physical and mechanical properties of eight fast-growing plantation species in Costa Rica. Journal of Tropical Forest Science, New York, v. 22, n. 3, p. 317-328, 2010.

MUÑOZ, G. R.; GETÉ, A. R. Prediction of bending strength in Oak beams of the basis of elasticity, density and wood defects. Journal of Materials in Civil Engineering, Reston, v. 24, n. 6, p. 629-634, 2012.

NAJI, H. R.; BAKAR, E. S.; SAHRI, M. H.; SOLTANI, M.; HAMID, H. A.; EBADI, S. E. Variation in mechanical properties of two rubberwood clones in relation to planting density. Journal of Tropical Forest Science, New York, v. 26, n. 4, p. 503-512, 2014.

PÁNEK, M.; REINPRECHT, L. Effect of vegetable oils on the colour stability of four tropical woods during natural and artificial weathering. Journal of Wood Science, Vienna, v. 62, n. 1, p. 74-84, 2016.

PONNETH, D.; VASU, A. E.; EASWARAN, J. C.; MOHANDASS, A.; CHAUHAN, S. S. Destructive and nondestructive evaluation of seven hardwoods and analysis of data correlation. International Journal of the Biology, Chemistry, Physics, and Technology of Wood, Villeurbanne, v. 68, n. 8, p. 951-956, 2014.

SEVERO, E. T. D.; CALONEGO, F. W.; SANGÍGOLO, C. A. Physical and chemical changes in juvenile and mature woods of Pinus elliottii var. elliottii by thermal modification. European Journal of Wood and Wood Products, Vienna, v. 70, n. 5, p. 741-747, 2012.

SKARVELIS, M.; MANTANIS, G. I. Physical and mechanical properties of beech wood harvested in the Greek public forests. Wood Research, Bratislava, v. 58, n. 1, p. 123-129, 2013.

TRIANOSKI, R.; MATOS, J. L. M.; IWAKIRI, S.; PRATA, J. G. Avaliação das propriedades mecânicas da madeira de espécies de Pinus tropicais. Scientia Forestalis, Piracicaba, v. 42, n. 101, p. 21-28, 2014.

ZANUNCIO, A. J. V.; MOTTA, J. P.; SILVEIRA, T. A.; SÁ-FARIAS, E.; TRUGILHO, P. F. Physical and colorimetric changes in Eucalyptus grandis wood after heat treatment. BioResources, Raleigh, v. 9, n. 1, p. 293-302, 2014.

WANG, W.; ZHU, Y.; CAO, J.; GUO, X. Thermal modification of Southern pine combined with wax emulsion preimpregnation: effect on hydrophobicity and dimensional stability. International Journal of the Biology Chemistry Physics and Technology of Wood, Villeurbanne, v. 69, n. 4, p. 405-413, 2015.

WIEMANN, M. C.; BRUCE-WILLIAMSON, G. Testing a novel method to approximate wood specific gravity of trees. Forest Science, Washington, v. 58, n. 6, p. 577-591, 2012.

YEBOAH, D.; BURTON, A. J.; STORER, A. J.; OPUNI-FRIMPONG, E. Variation in wood density and carbon content of tropical plantation tree species from Ghana. New Forests, Vienna, v. 45, n. 1, p. 35-52, 2014.

Received: 2018/04/26

Accepted: 2019/03/25

Sci. For., Piracicaba, v. 47, n. 124, p. 686-695, dez. 2019

DOI: doi.org/10.18671/scifor.v47n124.10 